\title{
Pengembangan Mobile Learning Menggunakan Adobe Animate CC untuk Meningkatkan Motivasi dan Hasil Belajar Peserta Didik
}

\author{
Silvia $^{1}$, Imam Bukhori ${ }^{2}$ \\ 1 Pendidikan Administrasi Perkantoran, Universitas Negeri Malang \\ e-mail: silvia.1704125@students.um.ac.id \\ 2 Pendidikan Administrasi Perkantoran, Universitas Negeri Malang \\ e-mail: imam.bukhori.fe@um.ac.id
}

\begin{abstract}
The Covid-19 pandemic that occurred since the end of 2019 is spreading rapidly to countries in the world, including Indonesia. Many sectors have been affected by this pandemic, including the education sector. Learning is no longer done face-toface but done remotely. The purpose of this research and development is to 1) produce android-based mobile learning in correspondence subjects, 2) know the level of feasibility of mobile learning through expert validation and trials, 3) know the differences in motivation and learning outcomes of learners. The research and development method used is the research and development method of Borg \& Gall which has been modified into seven steps: 1) the initial stage of research and information collection; 2) planning stage; 3) initial product format development stage; 4) expert validation stage; 5) product trial stage; 6) product revision stage; and 7) final product stage. Data collection instruments using media expert validation questionnaires, material expert validation questionnaires, test questionnaires, learner motivation level questionnaires, and posttests. Validation results and trials were declared very feasible and the application of the product successfully increased the motivation and learning outcomes of learners.
\end{abstract}

Keywords: learning motivation, learning outcomes, mobile learning.

\begin{abstract}
Abstrak
Pandemi Covid-19 yang terjadi sejak akhir 2019 menyebar dengan cepat ke negara-negara di dunia, tidak terkecuali Indonesia. Banyak sektor telah terdampak oleh pandemi ini, Tidak terkecuali sektor pendidikan. Pembelajaran tidak lagi dilakukan secara tatap muka tapi dilakukan secara jarak jauh. Tujuan dari penelitian dan pengembangan ini adalah untuk 1) menghasilkan mobile learning berbasis android pada mata pelajaran korespondensi, 2) mengetahui
\end{abstract}


tingkat kelayakan mobile learning melalui validasi ahli dan uji coba, 3) mengetahui perbedaan motivasi dan hasil belajar peserta didik. Metode penelitian dan pengambangan yang digunakan adalah metode penelitian dan pengembangan dari Borg \& Gall yang telah dimodifikasi menjadi tujuh langkah: 1) tahap penelitian dan pengumpulan informasi awal; 2) tahap perencanaan; 3) tahap pengembangan format produk awal; 4) tahap validasi ahli; 5) tahap uji coba produk; 6) tahap revisi produk; dan 7) tahap produk akhir. Instrumen pengumpulan data menggunakan angket validasi ahli media, angket validasi ahli materi, angket uji coba, angket tingkat motivasi belajar peserta didik, dan posttest. Hasil validasi dan uji coba dinyatakan sangat layak dan penerapan produk berhasil meningkatkan motivasi dan hasil belajar peserta didik.

Kata Kunci: hasil belajar, mobile learning, motivasi belajar.

\section{PENDAHULUAN}

Pandemi Covid-19 telah terjadi sejak akhir tahun 2019 lalu menyebar dengan cepat ke negara-negara lain, termasuk Indonesia. Banyak sektor telah terdampak oleh pandemi ini, termasuk sektor pendidikan. Untuk mengatasi permasalahan ini, pemerintah telah membuat beberapa kebijakan diantaranya merupakan kebijakan physical distancing. Kebijakan physical distancing untuk memutuskan wabah memaksa perubahan dari proses pembelajaran secara tatap muka menjadi proses pebelajaran jarak jauh. Kegiatan belajar mengajar dilakukan dari rumah menggunakan ponsel, laptop, maupun komputer secara daring. Teknologi informasi dan komunikasi semakin berkembang pesat belakangan ini. Tidak ada halangan bagi siswa untuk melakukan pembelajaran dimanapun dan kapanpun melalui ponsel yang ada dalam genggaman. Mobile learning menjadi tren tersendiri dalam kegiatan belajar dan pembelajaran (Lestari et al., 2019; Sari and Nurcahyo, 2018; Uther, 2019). Mobile learning diartikan sebagai penggunaan perangkat seluler seperti ponsel, tablet, dan laptop untuk tujuan pengajaran dan pembelajaran (Sung et al., 2015). Android adalah platform untuk masa depan, karena menjadi platform seluler yang lengkap, terbuka, dan gratis (Said et al., 2018). Penggunaan smartphone sebagai media pembelajaran memungkinkan pembelajaran dilakukan dimanapun 
dan kapanpun dengan jangkauan yang luas untuk mengakses materi dan informasi pembelajaran (Drigas and Angelidakis, 2017; Said et al., 2018; Yusuf, 2019).

Motivasi belajar merupakan salah satu komponen penting dalam kegiatan belajar dan pembelajaran yang berpengaruh terhadap hasil belajar dari peserta didik sendiri (Sari and Nurcahyo, 2018). Hasil belajar merupakan hal yang penting dalam kegiatan belajar (Bernacki et al., 2020). Berdasarkan hasil wawancara yang dilakukan dengan guru mata pelajaran korespondensi yaitu Ibu Aina Niawaty, S.Pd menyatakan bahwa pembelajaran di SMKN 1 Malang menggunakan media powerpoint yang dibagikan kepada peserta didik melalui situs e-learning sekolah. Penelitian dan pengembangan ini dilakukan guna menarik perhatian peserta didik untuk lebih memahami materi yang diajarkan.

Berdasarkan penelitian sebelumnya yang telah dilakukan oleh (Dasmo et al., 2017; Saselah et al., 2017; Sibarani et al., 2019) didapatkan hasil bahwa penerapan mobile learning memiliki pengaruh positif bagi peserta didik. Berdasarkan pemaparan diatas mengenai pentingnya mobile learning dalam kegiatan belajar dan pembelajaran bagi peserta didik maka peneliti mengembangkan mobile learning berbasis android bernama KUY yang dapat digunakan dimana saja dan kapan saja sesuai dengan kegiatan pembelajaran di era pandemi ini. Produk yang telah dikembangkan selanjutnya akan diterapkan guna meningkatkan motivasi dan hasil belajar peserta didik.

\section{METODE PENELITIAN}

Peneliti melakukan penelitian dan pengembangan media pembelajaran menggunakan model R\&D oleh Borg and Gall (dalam Sugiyono, 2016:35-36). Peneliti memilih model ini karena tahapannya yang mudah dimengerti serta mendukung kebutuhan pembuatan produk yang peneliti kembangkan. Pada tahap pertama, peneliti melakukan penelitian dan pengumpulan informasi awal untuk mengetahui kebutuhan media pembelajaran di lapangan dengan melalukan observasi dan wawancara. Tahap kedua dilakukan perencanaan pengembangan 
aplikasi mulai dari desain, ikon, menu-menu pada aplikasi. Dalam tahap perencanaan juga dilakukan perencanaan serta evaluasi yang disesuaikan dengan silabus mata pelajaran korespondensi. Tahap ketiga peneliti melakukan pengembangan format produk awal dimulai dari pengumpulan bahan, pengelolaan bahan, dan proses produksi produk. Tahap keempat dan kelima peneliti melakukan validasi bersama dengan validator ahli media dan validator ahli materi serta enam peserta didik sebagai subjek uji coba untuk menilai aplikasi yang telah dikembangkan sebelum diujikan pada kelompok besar. Pada tahap keenam, peneliti melakukan revisi produk berdasarkan saran yang telah diberikan oleh validator dan subjek uji coba kemudian di uji cobakan kepada kelas eksperimen. Pada tahap terahir, peneliti telah menghasilkan produk berupa aplikasi KUY yang telah melalui tahapan uji coba dan revisi sehingga dapat digunakan oleh peserta didik kelas $\mathrm{X}$ OTKP sebagai media pembelajaran melalui android.

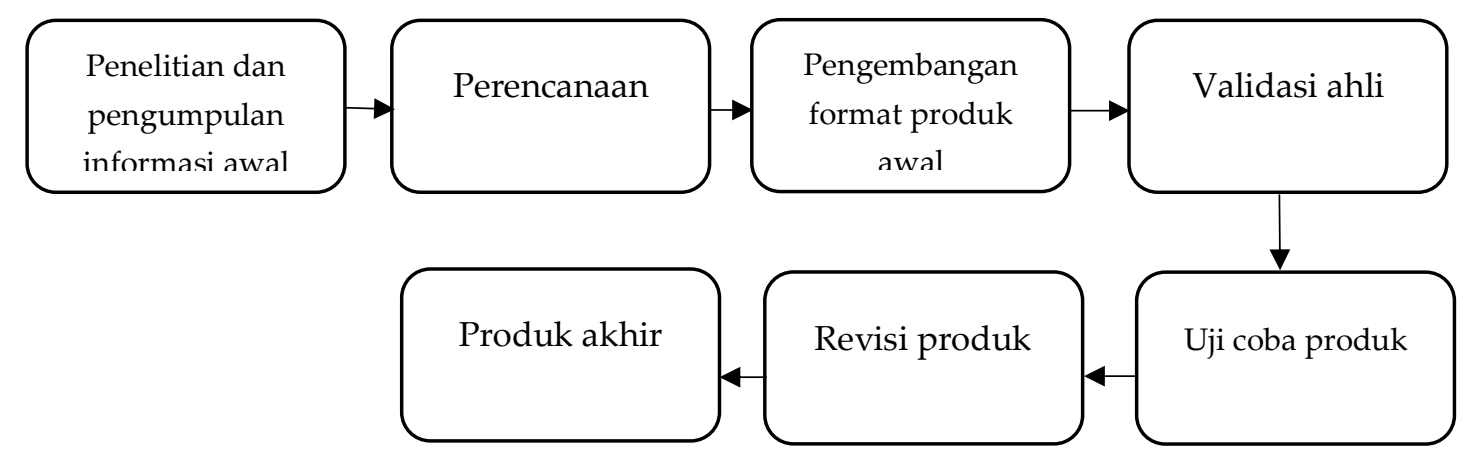

Gambar 1. Tahapan penelitian dan pengembangan Sumber: Sugiyono (2016)

Data yang diperoleh dari penelitian dan pengembangan ini berupa empat data yaitu 1). Data penilaian dan masukan dari ahli media dan ahli materi terhadap aplikasi KUY, 2). Data tanggapan peserta didik sebagai subjek uji coba pengguna terhadap aplikasi KUY, 3). Data dari kuisioner motivasi belajar peserta didik baik dari kelas eksperimen maupun kelas kontrol, dan 4). Data dari pelaksanaan posttest yang dilakukan terhadap peserta didik dari kelas eksperimen maupun kelas kontrol. 


\section{HASIL DAN PEMBAHASAN}

1. Hasil Penelitian dan Pengembangan

Produk yang dihasilkan dalam penelitian dan pengembangan ini adalah mobile learning berbasis android bernama KUY (Korespondensi Untuk Yeorobun/semua) pada mata pelajaran korespondensi yang dapat diunduh melalui link bit.ly/aplikasikuy. Dalam aplikasi KUY terdapat lima kompetensi dasar berupa fitur materi dan juga evaluasi yang dapat digunakan bagi peserta didik kelas X kompetensi keahlian otomatisasi tata kelola perkantoran. Tampilan menu pada aplikasi KUY dapat dilihat pada gambar dibawah ini.

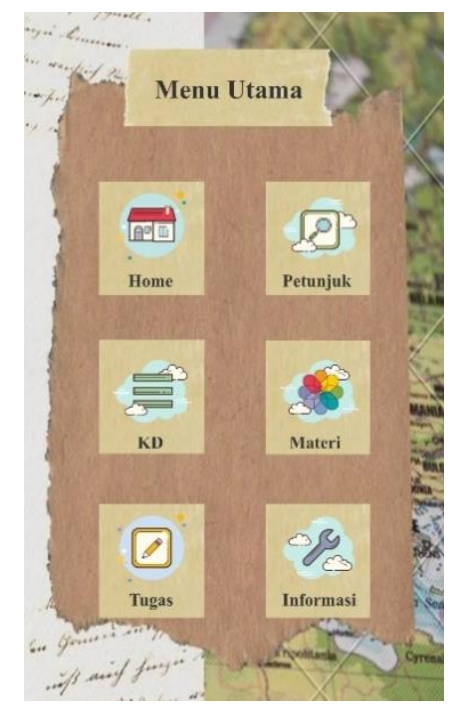

Gambar 2. Tampilan menu utama aplikasi KUY

Dalam aplikasi KUY terdapat enam menu berupa 1) Home, 2) Petunjuk, 3) Kompetensi Dasar, 4) Materi, 5) Tugas, dan 6) Informasi. Aplikasi KUY dirancang dengan desain yang semenarik mungkin agar peserta didik mendapat kemudahan dan merasa semangat dalam melaksanakan pembelajaran jarak jauh. Aplikasi KUY memungkinkan pengguna untuk mengakses materi dan tugas tanpa ada batasan tempat dan waktu.

Materi yang ada dalam aplikasi KUY berupa teks, gambar-gambar, dan juga video yang terintegrasi dengan Youtube. Pada menu evaluasi, peserta didik dapat 
mengerjakan soal evaluasi dan melihat hasilnya setelah selesai mengerjakan dan mengirimkan kepada guru melalui link yang tersedia.
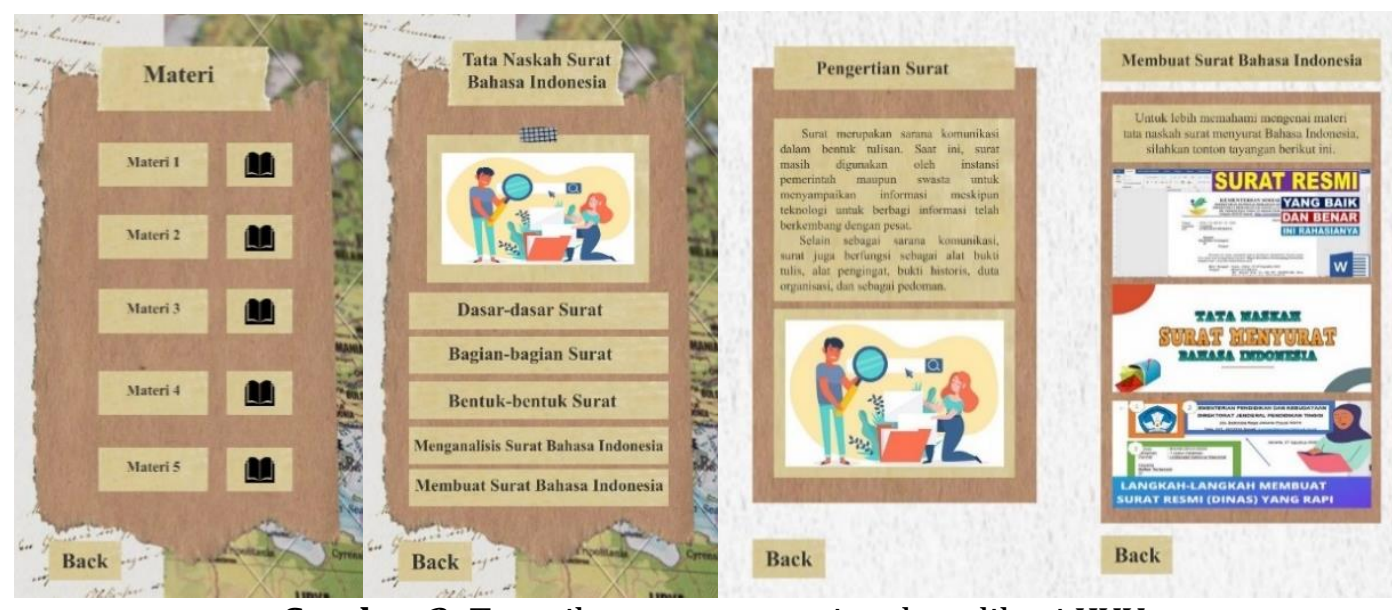

Gambar 3. Tampilan menu materi pada aplikasi KUY

Pada bagian menu materi pada aplikasi KUY, disajikan materi berupa teks dan gambar, serta video yang terintegrasi ke Youtube untuk memudahkan pengguna dalam mempelajari materi dan praktek.

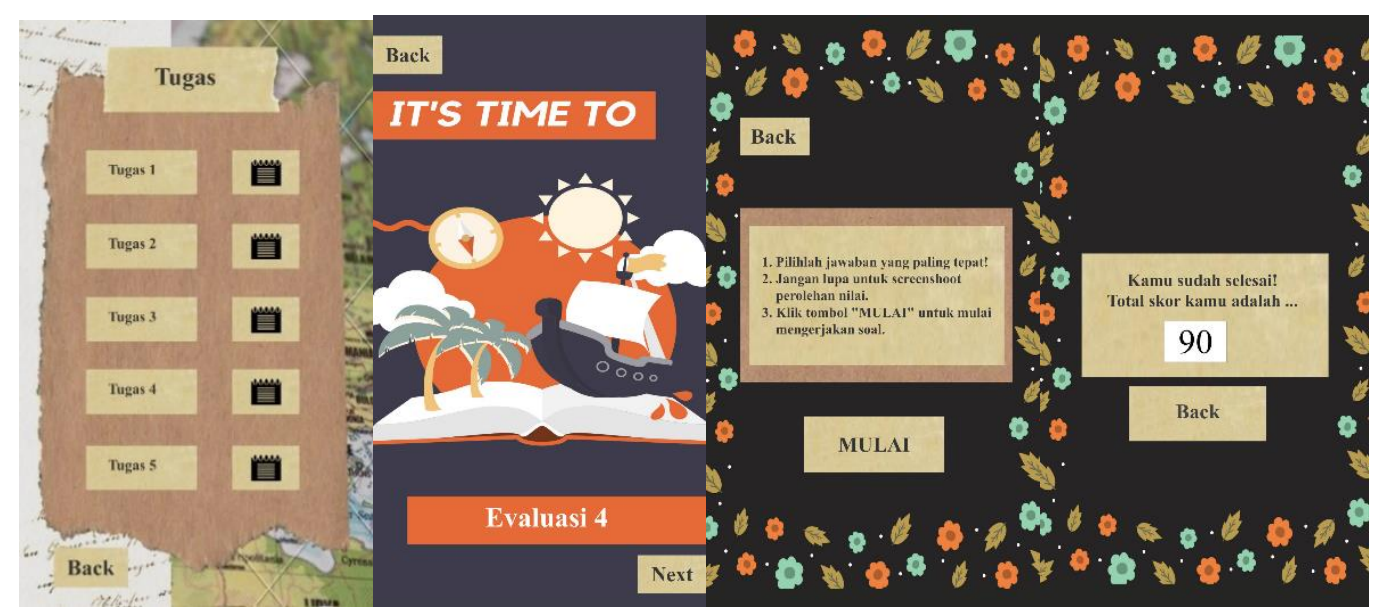

Gambar 4. Tampilan menu evaluasi pada aplikasi KUY

Selain materi, dalam aplikasi KUY juga terdapat evaluasi yang digunakan untuk memperluas pemahaman peserta didik dengan menjawab pertanyaanpertanyaan yang telah disediakan. Bagian evaluasi digunakan untuk mengukur hasil belajar peserta didik dalam ranah kognitif. Setelah selesai mengerjakan soal 
evaluasi, peserta didik dapat mengetahui langsung nilai yang diperoleh dan mengirimkan nilai yang diperoleh kepada guru melalui tombol yang terintegrasi dengan google form yang telah disediakan. Melalui pembelajaran menggunaan mobile learning ini, peserta didik tidak hanya mempelajari materi, akan tetapi juga melakukan evaluasi terhadap materi yang telah dipelajari secara mandiri.

2. Hasil Validasi Ahli dan Uji Coba Kelompok Kecil

Aplikasi yang telah selesai dikembangkan selanjutnya dilakukan validasi ahli dan uji coba untuk mengetahui tingkat kelayakan dari aplikasi. Hal ini sesuai dengan penelitian yang dilakukan oleh (Dasmo et al., 2017) yang menghasilkan Pocket Mobile Learning melalui validasi ahli materi dan ahli media serta uji coba kelompok kecil dan mendapatkan kriteria sangat baik. Media pembelajaran yang dikembangkan oleh (Sukariasih et al., 2019) memperoleh hasil validasi dari ahli materi sebesar $81.67 \%$ dan validasi ahli pembelajaran sebesar $76.56 \%$ dalam kategori layak untuk digunakan. Hal tersebut serupa dengan penelitian (Widiyastuti et al., 2018) yang memperoleh kategori layak untuk digunakan sebagai media pembelajaran berdasarkan dari hasil validasi ahli dan uji coba lapangan.

Validasi ahli dilakukan oleh ahli media dan ahli materi, sedangkan uji coba kelompok kecil dilakukan oleh enam peserta didik berkemampuan heterogen dari kelas eksperimen. Hasil validasi aplikasi KUY oleh ahli materi, ahli media, dan peserta didik uji coba kelompok kecil secara keseluruhan berupa data kualitatif dan data kuantitatif. Dalam langkah tes atau uji coba terdapat tiga macam uji coba media yang harus dilewati, yaitu (1) uji perseorangan mencakup ahli materi dan ahli media; (2) uji kelompok kecill; (3) uji kelompok besar. Berikut ini disajikan data kuantitatif validasi dan subjek uji coba kelompok kecil dalam Tabel 1 berikut ini.

Tabel 1. Data hasil validasi dan uji coba keseluruhan

\begin{tabular}{cccc}
\hline No & Validasi & Persentase & Kriteria Validitas \\
\hline 1. & Ahli Media & $100 \%$ & Sangat Valid \\
\hline
\end{tabular}




\begin{tabular}{cccc} 
2. & Ahli Materi & $96.5 \%$ & Sangat Valid \\
\hline 3. & Uji Coba Kelompok Kecil & $97 \%$ & Sangat Valid \\
\hline Rata-rata & $\mathbf{9 7 . 8 \%}$ & Sangat Valid \\
\hline
\end{tabular}

Berdasarkan data yang tersaji dalam Tabel 1 rata-rata hasil validasi oleh ahli media, ahli materi, serta subjek uji coba kelompok kecil dari aplikasi KUY mendapatkan rata-rata sebesar $97.8 \%$ sehingga dapat disimpulkan bahwa aplikasi KUY sangat valid dan layak untuk digunakan sebagai media pembelajaran pada mata pelajaran korespondensi untuk peserta didik kelas $\mathrm{X}$ kompetensi keahlian otomatisasi tata kelola perkantoran.

\section{Hasil Kuisioner Tingkat Motivasi Belajar Peserta Didik}

Teknologi telah berkembang dengan sangat pesat (Komarudin et al., 2017). Salah satu dampak perkembangan teknologi dalam dunia pendidikan adalah penggunaan mobile learning. mobile learning merupakan perangkat pembelajaran yang melibatkan perangkat sehingga peserta didik dapat mengakses materi pembelajaran, petunjuk belajar, dan aplikasi pembelajaran tanpa dibatasi oleh ruang dan waktu dimanapun mereka berada (Warsita, 2018). penyediaan layanan mobile learning untuk siswa dan guru yang dapat dilakukan kapanpun dan dimanapun menunjukkan hasil yang mencakup persepsi positif siswa, memudahkan siswa berkonsentrasi, fleksibilitas akses untuk layanan materi pembelajaran, dan meningkatkan ketrampilan siswa dalam menggunakan teknologi seluler (El-Sofany and El-Haggar, 2020). Penerapan mobile learning dapat meningkatkan hasil belajar siswa pada ranah kognitif (Sibarani et al., 2019).

Motivasi merupakan salah satu komponen penting dalam kegiatan belajar mengajar. Menurut Mc. Donald (dalam Sardiman, 2004:73) motivasi adalah perubahan energi dalam diri seseorang berupa munculnya feeling dan didahului dengan tanggapan terhadap adanya tujuan. Uno (2008:23) mengemukakan bahwa motivasi belajar dalam diri peserta didik timbul karena dua faktor, yaitu faktor intrinsik dan faktor ekstrinsik. Dalam kegiatan pembelajaran, motivasi 
memiliki peranan yang cukup penting. Muhammad (2016) mengemukakan bahwa siswa yang memiliki motivasi belajar tinggi akan selalu berusaha untuk lebih baik dan dipandang sebagai siswa yang berhasil dalam lingkungannya. Sedangkan siswa yang tidak memiliki motivasi belajar tidak menunjukkan kesungguhan dalam belajar sehingga hasil belajar ang diperoleh kurang memuaskan.

Untuk mengukur tingkat motivasi belajar peserta didik, dalam penlitian ini peneliti menggunakan kuisioner yang dikembangkan dari Uno (2008). Terdapat enam indikator, yakni adanya hasrat dan keinginan berhasil, adanya dorongan dan kebutuhan dalam belajar, adanya harapan dan cita-cita masa depan, adanya penghargaan dalam belajar, adanya kegiatan yang menarik dalam belajar, serta adanya lingkungan belajar yang kondusif, sehingga memungkinkan seseorang siswa untuk belajar dengan baik. Enam indikator tersbut kemudian dikembangkan menjadi 15 butir pernyataan yang dibagikan kepada peserta didik kelas eksperimen dan kelas kontrol melalui pengisian kuisioner di google form. Berikut ini disajikan data kuantitatif hasil kuisioner tingkat motivasi belajar peserta didik dalam Tabel 2 pada halaman selanjutnya.

Tabel 2. Data hasil kuisioner tingkat motivasi belajar peserta didik

\begin{tabular}{|c|c|c|c|}
\hline \multirow[b]{2}{*}{ Aspek } & \multirow[b]{2}{*}{ Indikator } & \multicolumn{2}{|c|}{ Rata-rata Skor } \\
\hline & & $\begin{array}{c}\text { Kelas } \\
\text { Eksperimen }\end{array}$ & $\begin{array}{c}\text { Kelas } \\
\text { Kontrol }\end{array}$ \\
\hline \multirow[t]{3}{*}{$\begin{array}{l}\text { Adanya hasrat dan } \\
\text { keinginan berhasil }\end{array}$} & $\begin{array}{l}\text { Saya semangat dalam } \\
\text { mepelajari materi pembelajaran }\end{array}$ & 3.5 & 3.1 \\
\hline & $\begin{array}{l}\text { Saya yakin mampu memahami } \\
\text { materi pembelajaran dengan } \\
\text { baik }\end{array}$ & 3.4 & 3.1 \\
\hline & $\begin{array}{l}\text { Saya cukup ulet dalam } \\
\text { mempelajari materi } \\
\text { pembelajaran }\end{array}$ & 3.2 & 2.7 \\
\hline \multirow[t]{2}{*}{$\begin{array}{l}\text { Adanya dorongan dan } \\
\text { kebutuhan dalam belajar }\end{array}$} & $\begin{array}{l}\text { Rasa ingin tahu saya terpacu } \\
\text { saat mempelajari materi } \\
\text { pembelajaran }\end{array}$ & 3.6 & 2.9 \\
\hline & $\begin{array}{l}\text { Minat belajar saya meningkat } \\
\text { saat mempelajari materi } \\
\text { pembelajaran }\end{array}$ & 3.2 & 2.8 \\
\hline
\end{tabular}




\begin{tabular}{|c|c|c|c|}
\hline & $\begin{array}{l}\text { Saya memiliki inisiatif untuk } \\
\text { menelaah kembali materi guna } \\
\text { meningkatkan pemahaman }\end{array}$ & 3.3 & 2.4 \\
\hline \multirow[t]{3}{*}{$\begin{array}{l}\text { Adanya harapan dan cita- } \\
\text { cita masa depan }\end{array}$} & $\begin{array}{l}\text { Saya menetapkan tujuan dalam } \\
\text { belajar }\end{array}$ & 3.3 & 3.2 \\
\hline & $\begin{array}{l}\text { Saya memiliki ketekunan dalam } \\
\text { belajar }\end{array}$ & 3.3 & 2.9 \\
\hline & $\begin{array}{l}\text { Saya memiliki keyakinan akan } \\
\text { keberhasilan dalam belajar }\end{array}$ & 3.7 & 3.5 \\
\hline \multirow[t]{2}{*}{$\begin{array}{c}\text { Adanya penghargaan } \\
\text { belajar }\end{array}$} & $\begin{array}{l}\text { Minat belajar saya terpacu saat } \\
\text { diberi pujian }\end{array}$ & 3 & 2.5 \\
\hline & $\begin{array}{l}\text { Minat belajar saya terpacu saat } \\
\text { diberi rewards }\end{array}$ & 3.1 & 2.3 \\
\hline \multirow[t]{2}{*}{$\begin{array}{l}\text { Adanya kegiatan yang } \\
\text { menarik dalam belajar }\end{array}$} & $\begin{array}{l}\text { Saya akan bertanya kepada guru } \\
\text { apabila ada materi yang belum } \\
\text { saya pahami }\end{array}$ & 3.1 & 2.4 \\
\hline & $\begin{array}{l}\text { Saya mencatat materi } \\
\text { pembelajaran }\end{array}$ & 3.4 & 3 \\
\hline \multirow{4}{*}{$\begin{array}{c}\text { Adanya lingkungan belajar } \\
\text { yang kondusif }\end{array}$} & $\begin{array}{l}\text { Saya lebih nyaman belajar } \\
\text { dalam lingkungan yang kondusif } \\
\text { dan tenang }\end{array}$ & 3.7 & 3.5 \\
\hline & $\begin{array}{l}\text { Saya lebih nyaman belajar } \\
\text { dalam kondisi yang rapi }\end{array}$ & 3.7 & 3.6 \\
\hline & Rata-rata Keseluruhan Aspek & 3.4 & 2.9 \\
\hline & Persentase & $85 \%$ & $72 \%$ \\
\hline
\end{tabular}

Berdasarkan data yang telah tersaji pada Tabel 2 diketahui bahwa rata-rata keseluruhan aspek dari kuisioner tingkat motivasi belajar peserta didik pada kelas eksperimen adalah 3.4 dengan persentase 85\% atau dalam kategori tingkat motivasi belajar tinggi. Selanjutnya kelas kontrol memperoleh rata-rata 2.9 dengan persentase $72 \%$ atau dalam kategori tingkat motivasi belajar tinggi. Masing-masing dari kedua kelas memperleh kategori rata-rata tingkat motivasi belajar "Tinggi". Terdapat perbedaan pada nilai persentase dimana kelas eksperimen memperoleh rata-rata tingkat motivasi belajar yang lebih tinggi dibandingkan dengan kelas kontrol.

4. Hasil Posttest Kelas Eksperimen dan Kelas Kontrol

Selain digunakan untuk mengetahui tingkat motivasi belajar peserta didik, produk yang dikembangkan juga digunakan untuk mengetahui perbedaan hasil belajar peserta didik yang meggunakan aplikasi KUY dengan peserta didik yang 
tidak menggunakan. Hasil belajar dalam penelitian ini diketahui melalui pelaksanaan posttest. Suprijono (dalam Thobroni \& Mustofa, 2013:22) mengemukakan bahwa hasil belajar merupakan pola-pola perbuatan, nilai-nilai, pengertian-pengertian, sikap-sikap, apresiasi, dan ketrampilan. Bloom (dalam Thobroni \& Mustofa, 2013:23-24) menyebutkan hasil belajar mencakup tiga domain, domain kognitif, domain afektif, dan domain psikomotor. penelitian yang dilakukan oleh (Rahmaibu et al., 2016) menunjukkan hasil belajar kelas ekperimen lebih tinggi dibandingkan dengan kelas kontrol. Demikian pula dengan penelitian yang dilakukan oleh (Rahmawati and Mukminan, 2017), dan (Sibarani et al., 2019).

Uji posttest digunakan pada kelas eksperimen dan kelas kontrol untuk mengetahui perbedaan hasil belajar dari kedua kelas. Bentuk dan jumlah soal yang diberikan pada kelas eksperimen dan kelas kontrol sama. Kelas eksperimen mengerjakan soal evaluasi melalui aplikasi KUY, sedangkan kelas kontrol mengerjakan soal evaluasi melalui google form. Hasil posttest dari kelas eksperimen dan kelas kontrol disajikan dalam Tabel 4.3 pada halaman selanjutnya.

Tabel 3. Data hasil posttest

\begin{tabular}{|c|c|c|c|c|c|}
\hline \multirow[t]{2}{*}{ No. Absen } & \multicolumn{2}{|c|}{ Kelas Eksperimen } & \multirow[t]{2}{*}{ No. Absen } & \multicolumn{2}{|c|}{ Kelas Kontrol } \\
\hline & Nilai & $\begin{array}{c}\text { Ketercapaian } \\
\text { KKM (75) }\end{array}$ & & Nilai & $\begin{array}{c}\text { Ketercapaian } \\
\text { KKM (75) }\end{array}$ \\
\hline 1. & 80 & $\geq \mathrm{KKM}$ & 1. & 80 & $\geq \mathrm{KKM}$ \\
\hline 2. & 85 & $\geq \mathrm{KKM}$ & 2. & 95 & $\geq \mathrm{KKM}$ \\
\hline 3. & 75 & $\geq \mathrm{KKM}$ & 3. & 65 & $\leq \mathrm{KKM}$ \\
\hline 4. & 75 & $\geq \mathrm{KKM}$ & 4. & 55 & $\leq \mathrm{KKM}$ \\
\hline 5. & 75 & $\geq \mathrm{KKM}$ & 5. & 65 & $\leq \mathrm{KKM}$ \\
\hline 6. & 75 & $\geq \mathrm{KKM}$ & 6. & 70 & $\leq \mathrm{KKM}$ \\
\hline 7. & 80 & $\geq \mathrm{KKM}$ & 7. & 70 & $\leq \mathrm{KKM}$ \\
\hline 8. & 85 & $\geq \mathrm{KKM}$ & 8. & 75 & $\geq \mathrm{KKM}$ \\
\hline 9. & 85 & $\geq \mathrm{KKM}$ & 9. & 65 & $\leq \mathrm{KKM}$ \\
\hline 10. & 75 & $\geq \mathrm{KKM}$ & 10. & 95 & $\geq \mathrm{KKM}$ \\
\hline 11. & 80 & $\geq \mathrm{KKM}$ & 11. & 75 & $\geq \mathrm{KKM}$ \\
\hline 12. & 85 & $\geq \mathrm{KKM}$ & 12. & 45 & $\leq \mathrm{KKM}$ \\
\hline 13. & 85 & $\geq \mathrm{KKM}$ & 13. & 70 & $\leq \mathrm{KKM}$ \\
\hline 14. & 75 & $\geq \mathrm{KKM}$ & 14. & 70 & $\leq \mathrm{KKM}$ \\
\hline 15. & 100 & $\geq \mathrm{KKM}$ & 15. & 65 & $\leq \mathrm{KKM}$ \\
\hline
\end{tabular}




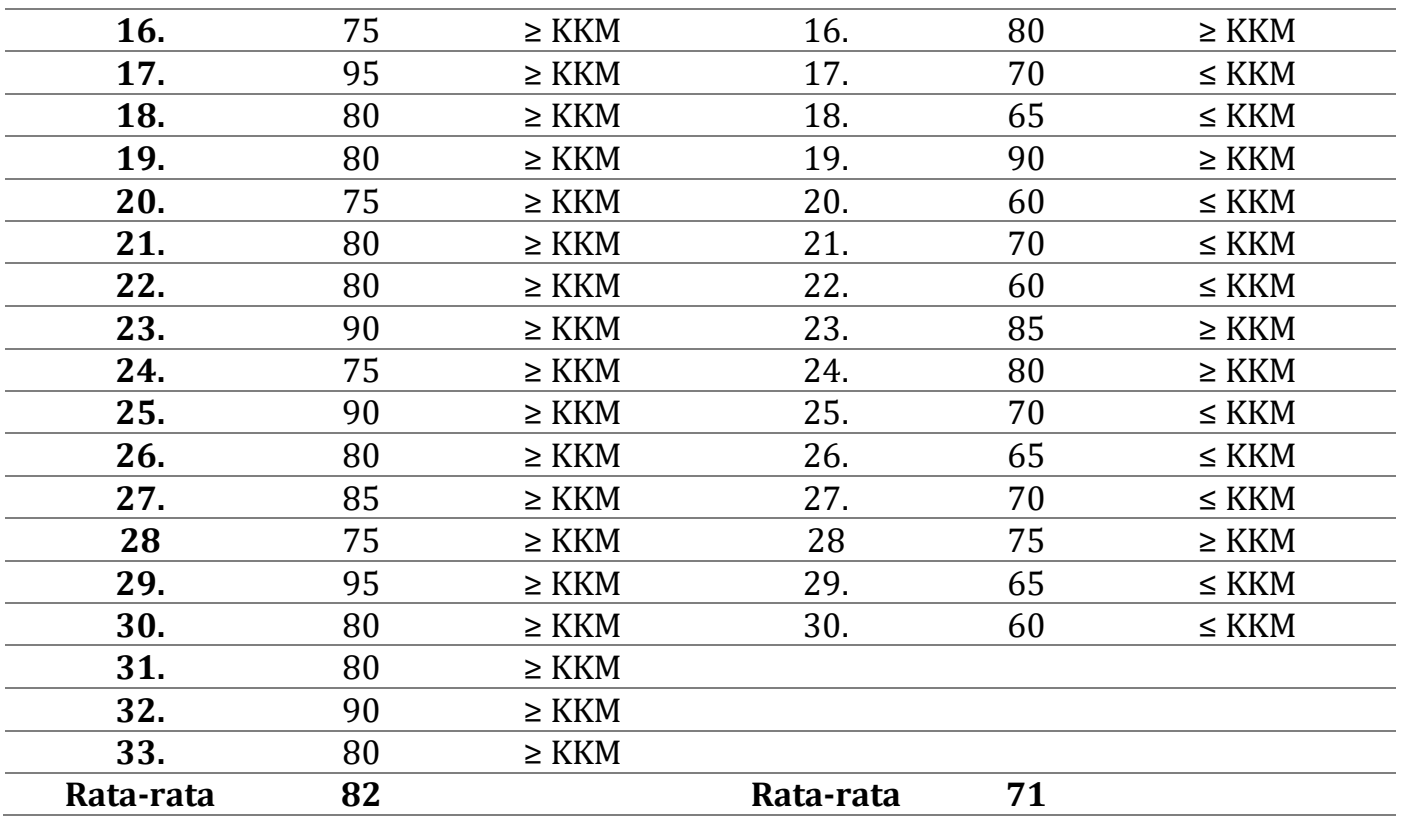

Berdasarkan data yang telah dipaparkan pada Tabel 4.8 dapat dilihat perhitungan hasil posttest menunjukkan rata-rata hasil belajar dari kelas eksperimen adalah 82 sedangkan dari kelas kontrol adalah 71. Peserta didik dari kelas eksperimen memiliki nilai diatas KKM, sedangkan dari kelas kontrol hanya beberapa peserta didik yang memiliki nilai diatas KKM. Hal ini menunjukkan bahwa penggunaan aplikasi KUY memiliki dampak terhadap hasil belajar peserta didik, dimana kelas yang menggunaan aplikasi KUY memiliki rata-rata hasil belajar yang lebih tinggi dibandingkan dengan kelas yang tidak menggunaan aplikasi KUY.

\section{KESIMPULAN}

Penelitian dan pengembangan ini menghasilkan aplikasi mobile learning bernama KUY (Korespondensi Untuk Yeorobun/semua) yang dapat dioperasikan melalui android. Aplikasi ini ditujukan untuk peserta didik kelas X kompetensi keahlian otomatisasi perkantoran dalam melakukan pembelajaran korespondensi. Hasil validasi ahli dan uji coba kelayakan aplikasi KUY secara keseluruhan menurut 
ahli materi, ahli media, dan uji coba kelompok kecil adalah sangat valid dan layak digunakan sebagai bahan ajar dalam proses pembelajaran.

Setelah dilakukan penelitian menggunakan mobile learning berbasis android bernama KUY pada KD 3.4 tata naskah surat menyurat bahasa Indonesia, terdapat perbedaan tingkat motivasi dan hasil belajar peserta didik kelas eksperimen dan kelas kontrol. Kelas eksperimen yang menggunakan produk yang dikembangkan memiliki tingkat motivasi dan hasil belajar yang lebih tinggi dibandingkan dengan kelas kontrol yang tidak menggunakan produk yang dikembangkan.

Penelitian dikatakan berhasil dengan dibuktikan bahwa Aplikasi KUY secara efektif dapat meningkatkan motivasi dan hasil belajar peserta didik ditinjau dari rata-rata kuisioner tingkat motivasi belajar dan uji posttest dari kelas eksperimen selaku kelas yang menggunakan aplikasi KUY lebih tinggi dibandingkan dengan kelas kontrol yang tidak menggunakan aplikasi KUY.

\section{DAFTAR RUJUKAN}

Bernacki, M.L., Vosicka, L., Utz, J.C., Warren, C.B., 2020. Effects of digital learning skill training on the academic performance of undergraduates in science and mathematics. Journal of Educational Psychology No Pagination Specified-No Pagination Specified. https://doi.org/10.1037/edu0000485

Dasmo, D., Astuti, I.A.D., Nurullaeli, N., 2017. Pengembangan Pocket Mobile Learning Berbasis Android. Jurnal Riset dan Kajian Pendidikan Fisika 4, 71-77. https://doi.org/10.12928/jrkpf.v4i2.7363

Drigas, A., Angelidakis, P., 2017. Mobile Applications within Education: An Overview of Application Paradigms in Specific Categories. International Journal of Interactive Mobile Technologies (iJIM) 11, 17-29.

El-Sofany, H.F., El-Haggar, N., 2020. The Effectiveness of Using Mobile Learning Techniques to Improve Learning Outcomes in Higher Education. International Journal of Interactive Mobile Technologies (iJIM) 14, 4-18.

Komarudin, D., Adnan, A., Upe, A.A., 2017. The Effect of Smartphone Technology Development on Student Morality. International Journal of Nusantara Islam 5 , 142-153. https://doi.org/10.15575/ijni.v5i2.2048 
Lestari, I., Maksum, A., Kustandi, C., 2019. Mobile Learning Design Models for State University of Jakarta, Indonesia. International Journal of Interactive Mobile Technologies (iJIM) 13, 152-171.

Rahmaibu, F.H., Ahmadi, F., Prasetyaningsih, F.D., 2016. Pengembangan Media Pembelajaran Menggunakan Adobe Flash Untuk Meningkatkan Hasil Belajar PKN. Jurnal Kreatif: Jurnal Kependidikan Dasar 7. https://doi.org/10.15294/kreatif.v7i1.9362

Rahmawati, E.M., Mukminan, M., 2017. Pengembangang m-learning untuk mendukung kemandirian dan hasil belajar mata pelajaran Geografi. Jurnal Inovasi Teknologi Pendidikan 4, 157-166. https://doi.org/10.21831/jitp.v4i2.12726

Said, K., Kurniawan, A., Anton, O., 2018. Development of media-based learning using android mobile learning. Journal of Theoretical and Applied Information Technology 96, 668-676.

Sardiman, A.M. 2004. Interaksi dan Motivasi Belajar Mengajar. Jakarta: PT Raja Grafindo Persada.

Sari, M., Nurcahyo, H., 2018. Improving students learning motivation through mobile learning. Jurnal Pendidikan Biologi Indonesia 4. https://doi.org/10.22219/jpbi.v4i3.6859

Saselah, Y.R., M, M.A., Qadar, R., 2017. Interactive Multimedia Development Based on Adobe Flash CS6 Profesional on Learning of Chemical Equilibrium. JKPK (Jurnal Kimia dan Pendidikan Kimia) 2, 80-89. https://doi.org/10.20961/jkpk.v2i2.11978

Sibarani, H.P., Komaro, M., Sukrawan, Y., 2019. Implementasi Mobile Learning Berbasis Aplikasi Smartphone Untuk Meningkatkan Hasil Belajar Siswa Pada Mata Pelajaran Teknik Pemesinan Bubut. Journal of Mechanical Engineering Education 6, 42-50. https://doi.org/10.17509/jmee.v6i1.18240

Sukariasih, L., Erniwati, E., Salim, A., 2019. Development of Interactive Multimedia on Science Learning Based Adobe Flash CS6. International Journal for Educational and Vocational Studies 1, 322-329. https://doi.org/10.29103/ijevs.v1i4.1454

Sung, Y.-T., Chang, K., Liu, T.-C., 2015. The Effects of Integrating Mobile Devices with Teaching and Learning on Students' Learning Performance: A Meta-Analysis and Research Synthesis. Computers \& Education 94. https://doi.org/10.1016/j.compedu.2015.11.008

Thobroni, M., Mustofa. 2013. Belajar dan Pembelajaran. Yogakarta: Ar Ruzz Media. 
Uno, Hamzah B. 2008. Teori Motivasi \& Pengukurannya: Kajian \& Analisis di Bidang Pendidikan. Jakarta: Bumi Aksara.

Uther, M., 2019. Mobile Learning-Trends and Practices. Education Sciences 9, 33. https://doi.org/10.3390/educsci9010033

Warsita, B., 2018. Mobile Learning Sebagai Model Pembelajaran Yang Efektif Dan Inovatif. Jurnal Teknodik 14, 062-073. https://doi.org/10.32550/teknodik.v14i1.452

Widiyaningtyas, T., Widiatmoko, A., 2014. Media Pembelajaran Berbasis Web Pada Mata Pelajaran Kimia. Jurnal Teknologi 21, 47-51.

Widiyastuti, N., Slameto, S., Radia, E.H., 2018. Pengembangan Media Pembelajaran Interaktif Menggunakan Software Adobe Flash Materi Bumi Dan Alam Semesta. Perspektif Ilmu Pendidikan 32, 77-84. https://doi.org/10.21009/PIP.321.9

Yusuf, A.S., 2019. Perancangan Media Pembelajaran IPA Terpadu Berbasis Computer Assisted Instruction Model Tutorial pada Topik Fotosintesis Menggunakan Adobe Animate CC untuk SMP. Proceeding Biology Education Conference: Biology, Science, Enviromental, and Learning 16, 42-48. 